\title{
Efficiency of boron application in an Oxisol cultivated with banana in the Central Amazon
}

\author{
ADÔNIS MOREIRA ${ }^{1}$, CÉSAR DE CASTRO ${ }^{2}$ and NAND K. FAGERIA ${ }^{3}$ \\ ${ }^{1}$ Embrapa Amazônia Ocidental, Caixa Postal 319, 69010-970 Manaus, AM, Brasil \\ ${ }^{2}$ Embrapa Soja, Caixa Postal 231, 86001-970 Londrina, PR, Brasil \\ ${ }^{3}$ Embrapa Arroz e Feijão, Caixa Postal 179, 75375-000 Santo Antônio de Goiás, GO, Brasil \\ Manuscript received on July 30, 2008; accepted for publication on September 24, 2010
}

\begin{abstract}
In the Amazon region, there is no information on the fertilization of banana plants with boron (B). Besides this, the extractant (hot water) currently used to test B concentrations has many limitations. The aim of this work was to study the effect of B on the fruit yield and quality of banana plants of the Cavendish (AAA) sub-group, grown in dystrophic Yellow Latosol (Oxisol or Xanthic Ferralsol), in the Amazonas State, Brazil. The experimental design was completely randomized split plot in a $4 \times 2$ factorial scheme, composed of four B rates $\left(0,4,8\right.$ and $\left.12 \mathrm{~kg} \mathrm{ha}^{-1}\right)$ and two harvest cycles (sub-treatments), with four replicates. The B availability in the soil was determined by three extractants: Mehlich 3 , hot water and $\mathrm{KCl} 1.0 \mathrm{~mol} \mathrm{~L}{ }^{-1}$. The application of B influences the fruit yield, pulp/peel ratio, pulp resistance and $\mathrm{B}$ content in the leaves and fruits. The $\mathrm{KCl} 1.0 \mathrm{~mol} \mathrm{~L}^{-1}$ extractant was similar to the hot water in the evaluation of available B. To obtain maximum yield, it is necessary to apply 4.1 and $6.1 \mathrm{~kg} \mathrm{ha}^{-1}$ of $\mathrm{B}$ in the first and second cycles, respectively.
\end{abstract}

Key words: Musa spp., yield, methods of soil analysis, post-harvest.

\section{INTRODUCTION}

Banana growing is among the agricultural activities in Brazil with the greatest economic importance and social range. Statistics indicate annual yield of some 7.1 million tonnes (metric tons), putting Brazil only behind the Philippines (7.5 million) and India (21.8 million). The cultivated area (540 thousand hectares) is even greater than in these countries, but the productivity is lower (FAOSTAT 2008).

In the Amazon region, banana plants were previously grown mainly in lowland areas, but with the increased infestation by diseases such as moko, or bacterial banana wilt (caused by Ralstonia solanacearum), and the arrival of black sigatoka (caused by Mycospharella fijiensis) in the region in 1998 (Gasparotto et al.

Correspondence to: Adônis Moreira

E-mail: adonis.moreira@cpaa.embrapa.br
2002), cultivation has largely migrated to areas of higher ground, with little influence of floods, locally called "várzea alta" ("high marshland") and "terra firme" ("upland soil"), respectively. The soils of these ecosystems are mostly less fertile and poorer in nutrients, with high acidity, low base sum and $\mathrm{H}^{+}+\mathrm{Al}^{3+}$ predominating in the soil exchange complex (Moreira and Fageria 2009a). Therefore, the switch to these areas has lowered the banana yield.

Moreira et al. (2005a) found that, in banana plants grown in five Amazon municipalities, except for phosphorus (P) and sulfur (S), the leaf concentration of the other nutrients analyzed [nitrogen $(\mathrm{N})$, potassium $(\mathrm{K})$, calcium $(\mathrm{Ca})$, magnesium $(\mathrm{Mg})$, boron $(\mathrm{B})$, copper $(\mathrm{Cu})$, iron $(\mathrm{Fe})$, manganese $(\mathrm{Mn})$ and zinc $(\mathrm{Zn})]$ were below the concentration considered adequate for this crop in same edaphoclimatic conditions (Moreira et al. 2005b). 
As part of fertilization, B plays an important role in the components of the cell membrane (Moraes et al. 2002), and especially in the K uptake (Loué 1993), which represents $41 \%$ of the total nutrients absorbed by banana plants (Silva et al. 1999). When there is a lack of B, the entire plant growth is halted, negatively affecting fruit yield (Loué 1993).

In Brazil, at the laboratories of soil fertility, the determination of available $\mathrm{B}$ is made in hot water solution (Berger and Truog 1939, Abreu et al. 2001), but other extractants were proposed due to the extraction of other elements as Mehlich 3 (Mehlich 1984) and KCl $1.0 \mathrm{~mol}$ $\mathrm{L}^{-1}$ (Moreira and Castro 2006). Concerning the acid extractant (Melich 3), that it extracts significant amounts of $\mathrm{Fe}$ in soil, and this can interfere in the determination of available $\mathrm{B}$ in soil, which hinders its interpretation (Ferreira et al. 2001).

The objective of this work was to investigate the effect of $B$ rates on the yield (first and second cycles) and fruit quality of banana plants (Nanicão 2001 - triploid AAA of the Cavendish sub-group) cultivated in a dystrophic Yellow Latosol - Oxisol (40\% of the soil in the Amazon region), and to evaluate the leaf and fruit content, associating them with the availability of B from the soil obtained by three extractants: hot water, Mehlich 3 and $\mathrm{KCl} 1.0 \mathrm{~mol} \mathrm{~L}^{-1}$.

\section{MATERIALS AND METHODS}

The experiment was conducted between April 2002 and December 2003, in the experimental field of Embrapa Western Amazon (CPAA), located at the geographic coordinates $3^{\circ} 8^{\prime} \mathrm{S}$ and $59^{\circ} 52^{\prime} \mathrm{W}$, in the municipality of Manaus, Amazonas State, Brazil.

The predominant climate in the region is moist tropical, classified as Afi on the Köppen scale, with relatively abundant rainfall throughout the year (average of $2,250 \mathrm{~mm}$ ) and high relative humidity. Precipitation in the driest months is always above $60 \mathrm{~mm}$, and the dry season lasts under two months. Average annual temperature (day and night) is about $26^{\circ} \mathrm{C}$ (Vieira and Santos 1987).

Due to the homogeneity of the soil, we used an entirely randomized experimental split plot design in a $4 \times 2$ factorial scheme, with four replicates. The treatments consisted of rates of $0,4,8$ and $12 \mathrm{~kg} \mathrm{ha}^{-1}$ of $\mathrm{B}$ [boric acid $\left(\mathrm{H}_{3} \mathrm{BO}_{3}\right)-18 \%$ of $\left.\mathrm{B}\right]$ and two harvest cycles (subtreatments). The treatments were applied in the same amount in the planting hole (first cycle) and after the harvest of the first bunch (second cycle), in a semicircle around the daughter plant (broadcast). Each plot was composed of five clumps plants.

The soil in the experimental area is a dystrophic Yellow Latosol (Oxisol) - Brazilian classification (Embrapa 1999), or Xanthic Ferralsol (FAO 1990), representing 2.0 million of $\mathrm{km}^{2}$ of total area in the Amazon region, and composed of $719.0 \mathrm{~g} \mathrm{~kg}^{-1}$ of clay, with the following chemical attributes: $\mathrm{pH}($ water $)=4.3$; organic matter $(\mathrm{OM})=46.92 \mathrm{~g} \mathrm{~kg}^{-1}$; P (Mehlich $1-0,025 \mathrm{~mol}$ $\left.\mathrm{L}^{-1} \mathrm{H}_{2} \mathrm{SO}_{4}+0,05 \mathrm{~mol} \mathrm{~L}^{-1} \mathrm{HCl}\right)=2.91 \mathrm{mg} \mathrm{dm}^{-3}$; $\mathrm{P}($ resin $)=9.83 \mathrm{mg} \mathrm{dm}^{-3} ; \mathrm{P}($ Mehlich 3) $=1.82 \mathrm{mg}$ $\mathrm{dm}^{-3} ; \mathrm{K}\left(\right.$ Mehlich 1) $=47.70 \mathrm{mg} \mathrm{dm}^{-3} ; \mathrm{Ca}(\mathrm{KCl} 1.0$ $\left.\mathrm{mol} \mathrm{L}{ }^{-1}\right)=0.22 \mathrm{cmol}_{\mathrm{c}} \mathrm{dm}^{-3} ; \mathrm{Mg}\left(\mathrm{KCl} 1.0 \mathrm{~mol} \mathrm{~L}^{-1}\right)=$ $0.10 \mathrm{cmol}_{\mathrm{c}} \mathrm{dm}^{-3} ; \mathrm{Al}\left(\mathrm{KCl} 1.0 \mathrm{~mol} \mathrm{~L}^{-1}\right)=1.51 \mathrm{cmol}_{\mathrm{c}}$ $\mathrm{dm}^{-3} ; \mathrm{H}+\mathrm{Al}$ (SMP buffer) $=8.02 \mathrm{cmol}_{\mathrm{c}} \mathrm{dm}^{-3} ; \mathrm{B}$ (hot water $)=0.31 \mathrm{mg} \mathrm{dm}^{-3} ; \mathrm{Cu}($ Mehlich 1$)=0.29 \mathrm{mg} \mathrm{dm}^{-3}$; Fe $\left(\right.$ Mehlich 1) $=333.10 \mathrm{mg} \mathrm{dm}^{-3} ;$ Mn (Mehlich 1) = $5.15 \mathrm{mg} \mathrm{dm}^{-3}$; and $\mathrm{Zn}$ (Mehlich 1) $=0.68 \mathrm{mg} \mathrm{dm}^{-3}$. The analyses were performed according to the procedures described in Embrapa (1997) and Moreira et al. (2004).

The planting holes $(60 \mathrm{~cm} \times 60 \mathrm{~cm} \times 60 \mathrm{~cm})$ were prepared 30 days before the application of limestone and, after planting, they were filled with five liters of powdered chicken manure and 400.0 grams of dolomitic limestone [effective calcium carbonate $(\mathrm{ECC})=$ $78 \%$ ] (Moreira et al. 2005b). Before the seedlings were planted, 300.0 grams of simple superphosphate $(20 \%$ $\left.\mathrm{P}_{2} \mathrm{O}_{5}\right), 5.0$ grams of copper sulfate $(13 \% \mathrm{Cu}), 20.0$ grams of iron sulfate $(19 \% \mathrm{Fe}), 5.0$ grams of manganese sulfate $(26 \% \mathrm{Mn})$ and 30.0 grams of zinc sulfate $(20 \% \mathrm{Zn})$ were placed in each hole. The spacing was three meters among rows and two meters among plants. The Nanicão 2001 cultivar (triploid AAA of the Cavendish sub-group) was used as the test plant. The plantation was developed leaving only the mothers, daughters and granddaughters plants in the clusters.

At the start of flowering, for each treatment, a sample was removed from the middle third of the third leaf (only the limb) counted from the apex, and at harvest time two bananas were taken from the second 


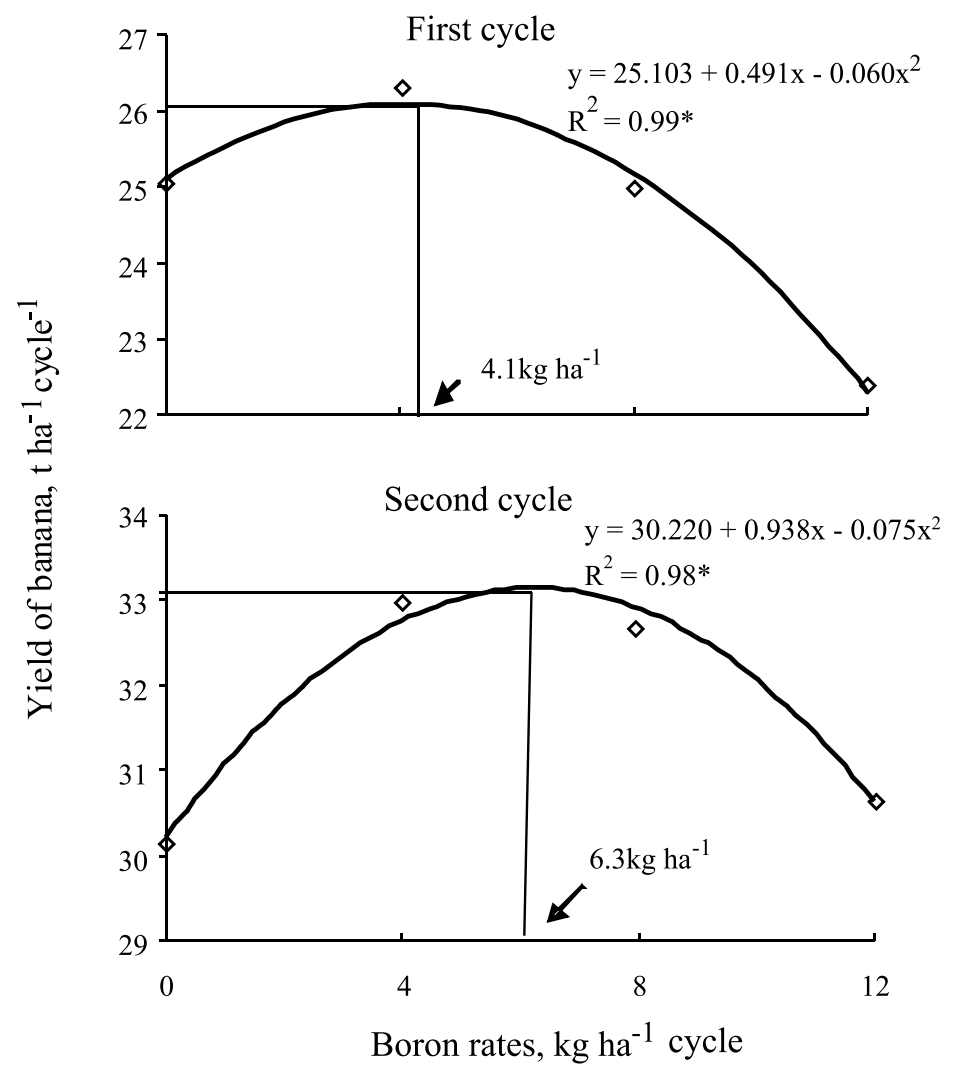

Fig. 1 - Yield of banana ( $\mathrm{t} \mathrm{ha}^{-1}$ cycle $^{-1}$ ) in the first and second cycles in response of $\mathrm{B}$ rates. *Significant at 5\% (first cycle) and 10\% (second cycle) level of probability - F-test.

hand. These two parts were dried in a forced air chamber at $65^{\circ} \mathrm{C}$ until reaching constant weight. Then, the $\mathrm{B}$ concentration of the leaves and fruits (pulp plus peel) samples were determined according to Malavolta et al. (1997).

In the two yield cycles the following variables were evaluated: bunch weight; bunch length; number of hands per bunch; weight of the second hand; number of fruits per hand; fruit length and diameter; pulp diameter; peel thickness; pulp/peel ratio, $\mathrm{pH}$ (acidity); total soluble solids (brix degree); and pulp resistance.

The estimated content $(\mathrm{Co})$ of $\mathrm{B}$ in the fruit was calculated by the equation: $\mathrm{Co}=$ nutrient concentration in the fruit $\times$ bunch yield [bunch weight - stalk weight $(2 \mathrm{~kg})]$, with the result expressed in $\mathrm{mg}$ plant $^{-1}$.

While the leaves were being collected, soil samples were being taken at a depth of $0-20 \mathrm{~cm}$ in the first flowering (first cycle) and at the same depth for the second flowering (second cycle). The available B in the soil was measured by spectrophotometry using the colorimetric reagent Azomethine $\mathrm{H}$ (Abreu et al. 2001), at a wavelength of $420 \mathrm{~nm}$, after extraction with hot water (Abreu et al. 2001), Melhich 3 (Mehlich 1984) and KCl $1.0 \mathrm{~mol}$ $\mathrm{L}^{-1}$ (Moreira and Castro 2006).

The results were submitted to variance analysis (ANOVA), the F-test, comparison of the means (Tukey's test at $5 \%$ ), regression and relationship, as described by Pimentel Gomes and Garcia (2002).

\section{RESULTS AND DISCUSSION}

The banana fruit yield increased according to a quadratic model with the enforcement of increasing rates of B (Fig. 1). The maximum productivities for the two cycles were obtained with respective rates of 4.1 and $6.3 \mathrm{~kg} \mathrm{ha}^{-1}$, corresponding to yields of 26.1 and $33.2 \mathrm{t}$ $\mathrm{ha}^{-1}$. These yields are $323.7 \%$ and $438.9 \%$ higher than the average in the Amazonas State, which is of around $6.2 \mathrm{tha}^{-1}$ (IBGE 2008).

The reduced fruit productivity due to higher $\mathrm{B}$ rates than the above ones possibly occurred because of the 
element's harmful effect, as cited by Malavolta et al. (1997), who state that B has narrow deficiency and toxicity ranges. In banana plants, B inhibits the growth of the meristematic tissues of the aerial part and roots, causing stunted leaf blades (possibly just to the main vein) with irregular undulated edges. In case of severe deficiency, necrosis can occur without previous chlorosis, mainly at the leaf ends, which become wilted (Silva et al. 1999, Moreira et al. 2010a).

The availability of B to plants is directly related to the concentration of organic matter and the soil $\mathrm{pH}$ (Fageria 2009). In a pH range of 4.0 to 8.0 , B is absorbed in the form of $\mathrm{H}_{3} \mathrm{BO}_{3}$ and $\mathrm{H}_{2} \mathrm{BO}_{3}^{-}$. Under the studied edaphoclimatic conditions, $50 \%$ of $\mathrm{B}$ is retained in the plant detritus, which is subsequently mineralized and again become available to the plants (Moreira and Fageria 2009b).

Despite the increase in yield, the B rates did not influence the bunch size, number of hands, weight and number of fruits on the second hand, fruit length, diameter and peel thickness. According to Gupta (1993), some factors might have affected the uptake of $\mathrm{B}$, such as the $\mathrm{pH}$, cation exchange capacity (CEC), water, organic matter $(\mathrm{OM})$, and particularly the nutrient's uptake due to the high clay content of the soil at this region.

An increasing concentration of B influenced the pulp/peel ratio, with a quadratic effect in the first cycle and a linear one in the second cycle (Table I). This behavior can be due to the amount of B applied in the first cycle. However, in the second cycle, with the distribution of fertilizers in a semicircle alongside the daughter plant, there was a reduced contact of the nutrient with the roots, enabling a greater uptake of B (Fig. 2).

The pulp resistance had a positive linear relationship with the rates in the two cycles (Table I). This effect possibly occurred due to the increased size of the cells (Loué 1993, Marschner 1995) and their greater cohesion because of the greater presence of calcium pectate (Moraes et al. 2002). These observations corroborate the findings of Loomis and Durst (1992) and Moraes et al. (2002), who argue that $B$ is responsible for stabilizing compounds of $\mathrm{Ca}$ with pectins, probably causing an increase in pulp consistency.

According to Bem-Arie and Sonego (1980), a low $\mathrm{B}$ content can also influence the activity of the enzymes pectin methylesterase and polygalacturonase, leading to an accumulation of de-esterified pectin substances responsible for pulp firmness. Ishii et al. (2001), in a study of pumpkin plants, showed that the addition of boric acid to plants deficient in this element results in the formation of two rhamnogalacturonan-B chains from two m-rhamnogalacturonan- $\mathrm{B}$ chains and repacking of the matrix into a firmer cell wall.

The B rates caused significant differences in the leaf concentrations, showing a linear response to the use of the nutrient (Fig. 2). In the control plants (no B applied), there was a $57 \%$ reduction in the concentration from the first to the second cycle. The estimated critical levels of $\mathrm{B}$ in the soil (depth of 0 to $20 \mathrm{~cm}$ ) for maximum yield for the first and second cycles, respectively, obtained by extraction with hot water, were 0.30 and $0.97 \mathrm{mg} \mathrm{kg}^{-1}$, while for $\mathrm{KCl}$ these were 1.13 and $1.70 \mathrm{mg} \mathrm{kg}^{-1}$, and for Mehlich 30.73 and $0.94 \mathrm{mg} \mathrm{kg}^{-1}$ (Fig. 3). Alvarez Venegas et al. (1999) reported that the adequate concentration of B available in hot water is between 0.36 and $0.90 \mathrm{mg} \mathrm{kg}^{-1}$.

A comparison of the leaf concentrations obtained against those considered adequate for the genus Musa spp. shows that among the estimated concentrations, only the two lowest rates in the first cycle caused leaf concentrations within the range considered adequate, of 10 to $25 \mathrm{mg} \mathrm{kg}^{-1}$ (Malavolta et al. 1997, Moreira et al. 2005b). At other rates, except for the control in the second cycle, the concentrations were above this range, and at a dose of $12 \mathrm{~kg} \mathrm{ha}^{-1}$ in the second cycle, the leaf content was $470 \%$ greater than in the control plants (Fig. 2). According to the same procedures used for available B in the soil, the critical B concentration in the leaves to obtain maximum potential yield in the first and second cycles were 26.9 and $78.7 \mathrm{mg} \mathrm{kg}^{-1}$, while in the fruits these were 18.3 and $15.0 \mathrm{mg} \mathrm{kg}^{-1}$, respectively. If using a sufficiency concentration of $25 \mathrm{mg} \mathrm{kg}^{-1}$ of B for banana plants indicated by Malavolta et al. (1997), the adequate amount would be 3.4 and $1.3 \mathrm{~kg} \mathrm{ha}^{-1}$ for the first and second cycles, respectively.

Salvador et al. (2003) studying guava trees, and Chapman et al. (1997) studying rice, lentils and peas, also did not detect a beneficial or deleterious effect on the yield of dry matter in function of B rates. Another factor that should be considered is that the B concen- 
TABLE I

Effect of B rates in parameters of growth and post-harvest of the first and second cycles of banana crop ${ }^{(1)}$.

\begin{tabular}{|c|c|c|c|c|c|c|}
\hline \multirow{2}{*}{ Cycles } & \multicolumn{4}{|c|}{ Boron rates $\left(\mathrm{kg} \mathrm{ha}^{-1}\right)$} & \multirow{2}{*}{ Equations } & \multirow{2}{*}{$\mathrm{R}^{2}$} \\
\hline & 0 & 4 & 8 & 12 & & \\
\hline & \multicolumn{6}{|c|}{ bunch length $(\mathrm{cm})-\mathrm{CV}(\%)=17.83$} \\
\hline $1^{\mathrm{st}}$ & $89.1 \mathrm{a}$ & $91.5 \mathrm{a}$ & $82.9 \mathrm{a}$ & $83.4 \mathrm{a}$ & NS & \\
\hline $2^{\text {nd }}$ & $\begin{array}{l}84.7 \mathrm{a} \\
\text { numbe }\end{array}$ & $\begin{array}{l}91.6 \mathrm{a} \\
\text { of hand }\end{array}$ & $\begin{array}{l}88.4 \mathrm{a} \\
\text { per bur }\end{array}$ & $\begin{array}{l}90.6 \mathrm{a} \\
\mathrm{h}-\mathrm{CV}(\%)=6.86\end{array}$ & NS & \\
\hline $1^{\mathrm{st}}$ & $9 \mathrm{a}$ & $9 \mathrm{a}$ & $9 \mathrm{a}$ & $9 \mathrm{a}$ & NS & \\
\hline $2^{\text {nd }}$ & $\begin{array}{c}10 \mathrm{a} \\
\text { weigh }\end{array}$ & $\begin{array}{l}10 a \\
\text { of the se }\end{array}$ & $\begin{array}{c}\text { 9a } \\
\text { ond har }\end{array}$ & $\begin{array}{l}10 \mathrm{a} \\
(\mathrm{g})-\mathrm{CV}(\%)=16.83\end{array}$ & weight of the second hand $(\mathrm{g})-\mathrm{CV}(\%)=16.83$ & \\
\hline $1^{\text {st }}$ & $2.3 \mathrm{a}$ & $2.2 \mathrm{a}$ & $2.2 \mathrm{~b}$ & $1.9 \mathrm{~b}$ & NS & \\
\hline $2^{\text {nd }}$ & $\begin{array}{l}2.7 \mathrm{a} \\
\text { numbe }\end{array}$ & $\begin{array}{l}2.5 \mathrm{a} \\
\text { of fruit }\end{array}$ & $\begin{array}{c}2.8 \mathrm{a} \\
\text { per han }\end{array}$ & $\begin{array}{l}2.6 \mathrm{a} \\
-\mathrm{CV}(\%)=8.59\end{array}$ & NS & \\
\hline $1^{\text {st }}$ & $15 \mathrm{a}$ & $15 \mathrm{a}$ & $16 b$ & $15 \mathrm{a}$ & NS & \\
\hline $2^{\text {nd }}$ & $\begin{array}{c}16 \mathrm{a} \\
\text { fruit le }\end{array}$ & $\begin{array}{c}15 \mathrm{a} \\
\text { gth }(\mathrm{cm}\end{array}$ & $\begin{array}{r}22 \mathrm{a} \\
-\mathrm{CV}(\end{array}$ & $\begin{array}{c}16 a \\
=5.88\end{array}$ & NS & \\
\hline $1^{\text {st }}$ & $21.3 \mathrm{a}$ & $21.2 \mathrm{a}$ & $20.8 \mathrm{a}$ & $20.4 \mathrm{a}$ & NS & \\
\hline $2^{\text {nd }}$ & $\begin{array}{l}21.1 \mathrm{a} \\
\text { fruit } \mathrm{d}\end{array}$ & $\begin{array}{c}20.6 \mathrm{a} \\
\text { meter }(\end{array}$ & $\begin{array}{l}20.0 \mathrm{a} \\
\mathrm{m})-\mathrm{C}\end{array}$ & $\begin{array}{l}18.7 \mathrm{a} \\
(\%)=6.65\end{array}$ & NS & \\
\hline $1^{\mathrm{st}}$ & $33.4 \mathrm{a}$ & $32.6 \mathrm{a}$ & $33.2 \mathrm{a}$ & $33.1 \mathrm{a}$ & NS & \\
\hline $2^{\text {nd }}$ & $\begin{array}{l}37.2 \mathrm{a} \\
\text { peel th }\end{array}$ & kness & $\begin{array}{r}37.3 \mathrm{a} \\
\mathrm{m})-\mathrm{C}\end{array}$ & $\begin{array}{l}36.3 a \\
(\%)=11.43\end{array}$ & NS & \\
\hline $1^{\text {st }}$ & $4.0 \mathrm{a}$ & $3.7 \mathrm{~b}$ & $3.7 \mathrm{a}$ & $4.0 \mathrm{a}$ & NS & \\
\hline $2^{\text {nd }}$ & $\begin{array}{c}4.3 \mathrm{a} \\
\text { pulp/p }\end{array}$ & $\begin{array}{l}4.5 \mathrm{a} \\
\text { el ratio }\end{array}$ & $\begin{array}{c}4.2 \mathrm{a} \\
\mathrm{CV}(\%)\end{array}$ & $\begin{aligned} & 4.0 \mathrm{a} \\
= & 11.95\end{aligned}$ & NS & \\
\hline $1^{\text {st }}$ & $1.03 \mathrm{a}$ & $1.10 \mathrm{a}$ & $1.12 \mathrm{a}$ & $0.99 \mathrm{a}$ & $\hat{\mathrm{y}}=1.025+0.035 * \mathrm{x}-0.003 * \mathrm{x}^{2}$ & 0.96 \\
\hline $2^{\text {nd }}$ & $\begin{array}{l}0.97 \mathrm{a} \\
\mathrm{pH}(\mathrm{ac}\end{array}$ & $\begin{array}{l}1.07 \mathrm{a} \\
\text { dity) }-\mathrm{C}\end{array}$ & $\begin{array}{l}1.12 \mathrm{a} \\
V(\%)=\end{array}$ & $\begin{array}{l}1.22 \mathrm{a} \\
.59\end{array}$ & $\hat{\mathrm{y}}=0.975+0.020 * \mathrm{x}$ & 0.99 \\
\hline $1^{\text {st }}$ & $4.6 \mathrm{a}$ & $4.6 \mathrm{a}$ & $4.6 \mathrm{a}$ & $4.7 \mathrm{a}$ & NS & \\
\hline $2^{\text {nd }}$ & $\begin{array}{l}4.8 \mathrm{a} \\
\text { total ss}\end{array}$ & \multicolumn{4}{|c|}{ total soluble solids (brix degree) $-\mathrm{CV}(\%)=20.16$} & \\
\hline $1^{\mathrm{st}}$ & $8.5 \mathrm{~b}$ & $9.5 \mathrm{~b}$ & $9.4 \mathrm{~b}$ & $8.7 \mathrm{~b}$ & $\hat{y}=8.525+0.331 * x-0.027 * x^{2}$ & 0.98 \\
\hline $2^{\text {nd }}$ & \multicolumn{6}{|c|}{ pulp resistance (Newton) $-\mathrm{CV}(\%)=17.02$} \\
\hline $1^{\text {st }}$ & $21.7 \mathrm{a}$ & $21.8 \mathrm{a}$ & $23.9 \mathrm{a}$ & $25.6 \mathrm{a}$ & $\hat{\mathrm{y}}=21.180+0.345 * \mathrm{x}$ & 0.91 \\
\hline $2^{\text {nd }}$ & $17.4 \mathrm{~b}$ & $18.3 \mathrm{~b}$ & $18.6 \mathrm{~b}$ & $19.0 \mathrm{~b}$ & $\hat{y}=17.560+0.127 * x$ & 0.97 \\
\hline
\end{tabular}

${ }^{(1)}$ Values followed by similar letters in the same column and variables are not significantly different at $p \leq 0.05$ by Tukey's test. *Significant at $5 \%$ level of probability. ${ }^{\mathrm{NS}}$ Non-significant by F-test. $\mathrm{R}^{2}-$ coefficient of determination.

tration considered adequate for most of food crops is highly variable, with many requirements for this nutrient being attributed to differences in the composition of the cell walls between various species and genotypes (Marschner 1995).
The B concentration in the fruits increased significantly with the rates of the nutrient. At a rate of $12 \mathrm{~kg}$ $\mathrm{ha}^{-1}$ the concentration in the fruits was $486 \mathrm{~g} \mathrm{ha}^{-1}$ and $547 \mathrm{~g} \mathrm{ha}^{-1}$ in the first and second cycles, respectively (Fig. 2). On average for the treatments and the two cy- 

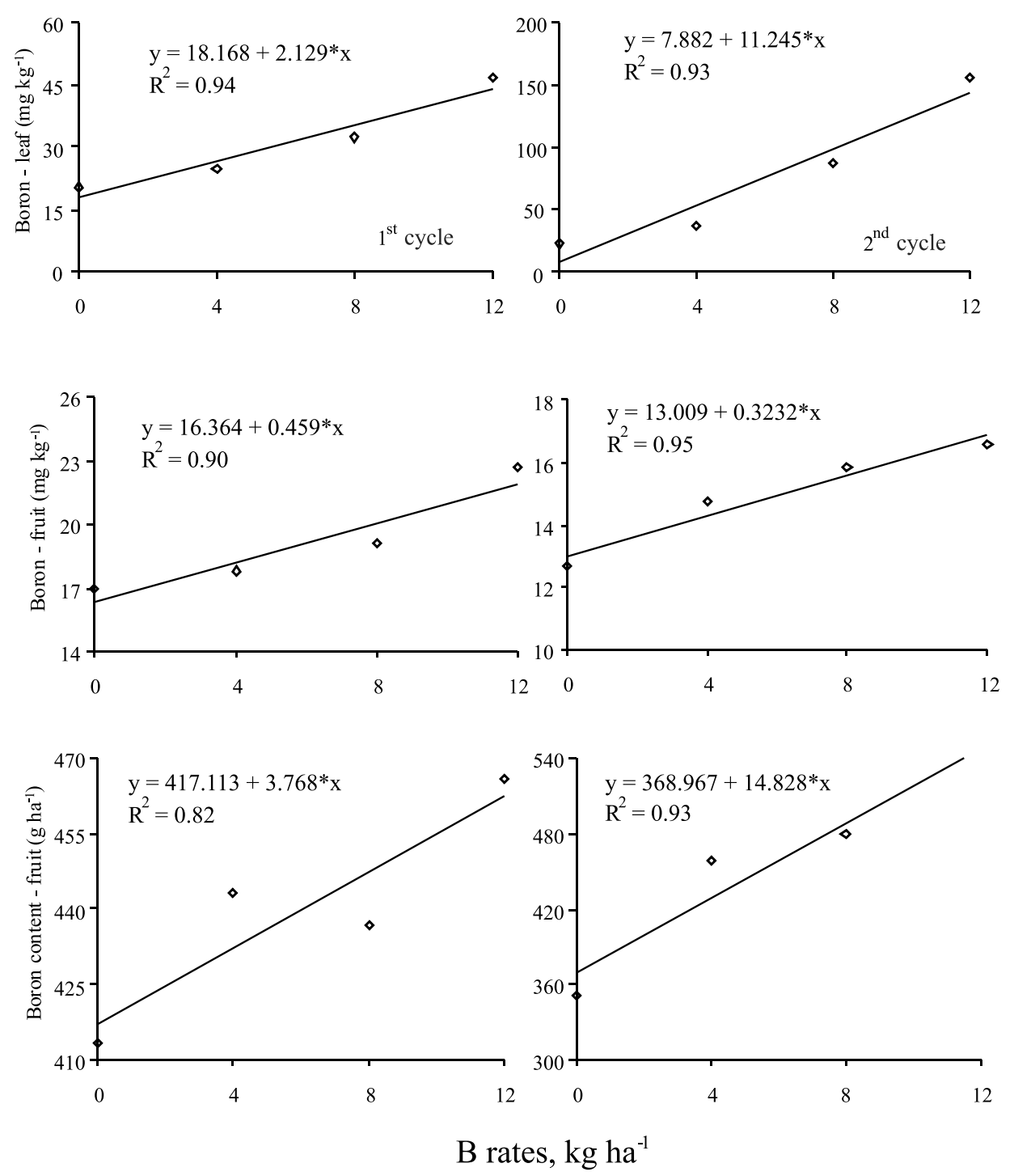

Fig. 2 - Equation of regression among the B rates with B concentration in leaves and fruits, and with B content in fruits of two yield cycles. Significant at $5 \%$ level of probability by F-test.

cles, the weights of many parts of the plants had the following division: $27.6 \%$ for the fruits (exported part), $9.9 \%$ for the leaves, $2.2 \%$ for the stems and $60.3 \%$ for the pseudo trunk.

The comparison of the available B concentrations in the soil recovered with the extractants and the levels in the diagnostic leaves removed at the start of flowering of the first and second cycles showed the following relationship coefficients between pairs of extractants: hot water and Mehlich $3(\mathrm{r}=0.89, p \leq 0.05)$, hot water and $\mathrm{KCl} 1.0 \mathrm{~mol} \mathrm{~L}^{-1}(\mathrm{r}=0.83, p \leq 0.05)$; and Mehlich 3 and $\mathrm{KCl} 1.0 \mathrm{~mol} \mathrm{~L}^{-1}(\mathrm{r}=0.67, p \leq 0.05)$. Figure 1 shows that the $\mathrm{KCl} 1.0 \mathrm{~mol} \mathrm{~L}^{-1}$ extractant was able to recover more $\mathrm{B}$ than the hot water and Mehlich 3 ones. Similar results were obtained by Moreira et al. (2010b), in greenhouse conditions with soybean. According to Jin et al. (1987), the presence of chloride ions in these extractants can cause a higher recovery capacity of the borate anions adsorbed in the positive charges of the colloids in the soil.

The advantage of $\mathrm{KCl} 1.0 \mathrm{~mol} \mathrm{~L}^{-1}$ over hot water as an extractant to measure the available $\mathrm{B}$ is that it can be introduced into the laboratory routine without the need to prepare another extract, since it is used to 

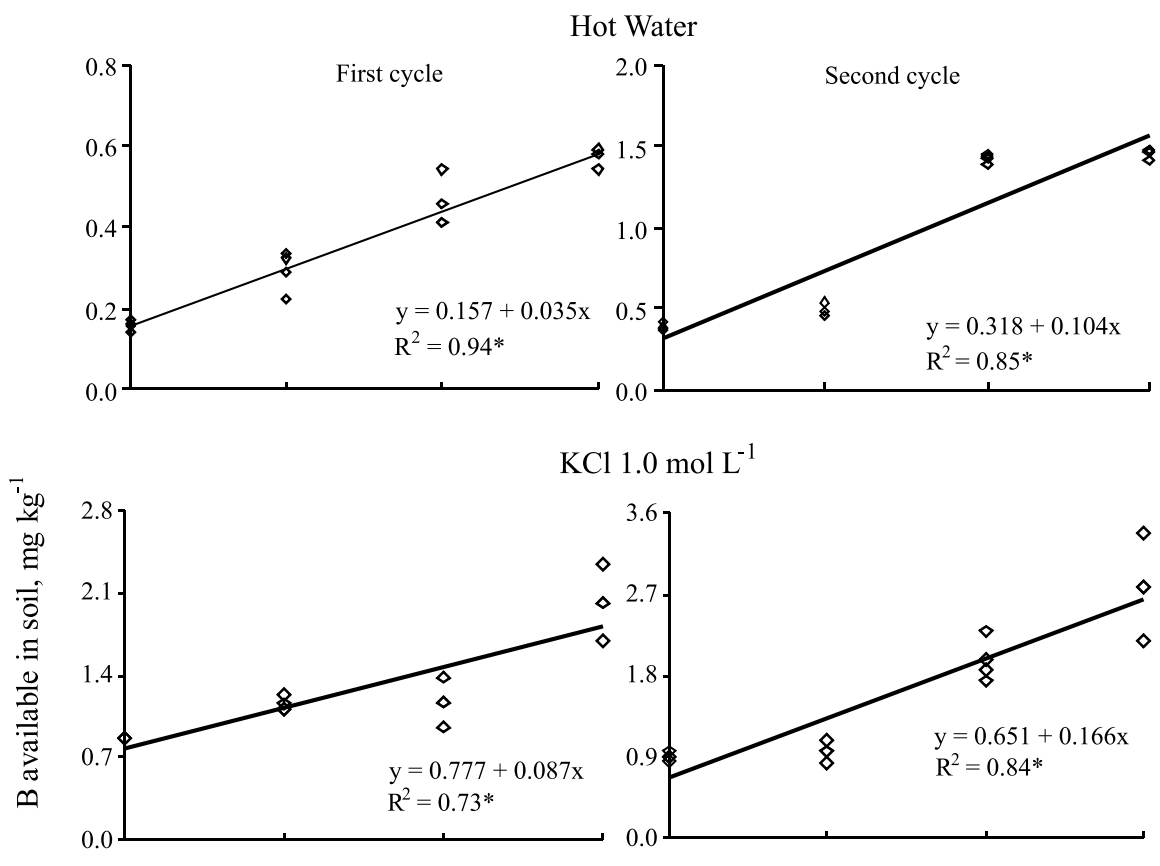

Mehlich 3

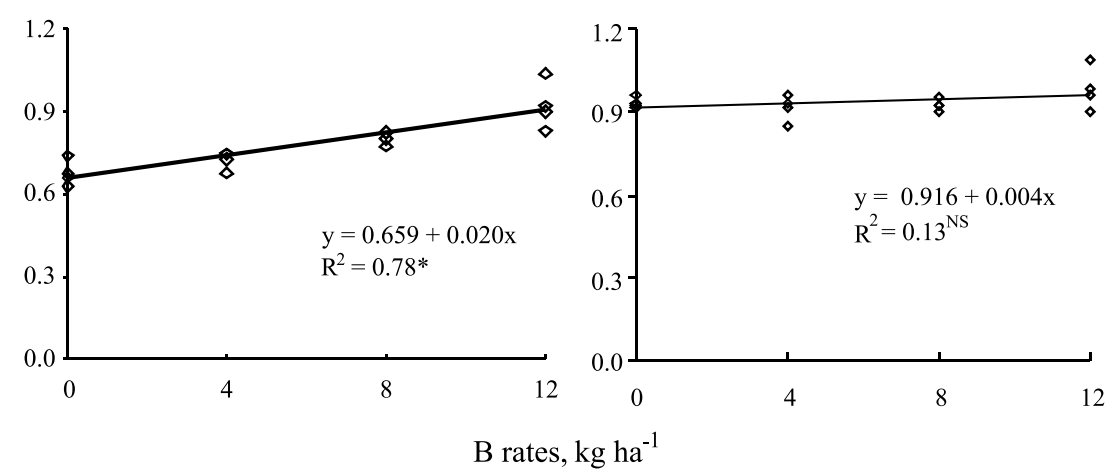

Fig. 3 - Equation of regression among B rates with B available in soil determined with Mehlich 1, KCl 1.0 mol L ${ }^{-1}$ and Mehlich 3 extractants. ${ }^{*}$ Significant at $5 \%$ level of probability. ${ }^{\mathrm{NS}}$ Non-significant by F-test.

determine $\mathrm{Ca}, \mathrm{Mg}$ and exchangeable $\mathrm{Al}$, while hot water is only used to determine the available B in the soil. In addition, this method has a greater extraction range. While for hot water the highest extracted $\mathrm{B}$ value was $1.48 \mathrm{mg} \mathrm{kg}^{-1}$, with $\mathrm{KCl} 1.0 \mathrm{~mol} \mathrm{~L}^{-1}$ this value was 3.37 $\mathrm{mg} \mathrm{kg}{ }^{-1}$, which improved the availability ranges and their interpretation as low, medium or high (Fig. 3).

\section{CONCLUSIONS}

1. In dystrophic Yellow Latosol - Oxisol (Xanthic Ferralsol) in the moist tropical Amazon, in the first two cycles, the $\mathrm{B}$ rates of 4.1 and $6.3 \mathrm{~kg} \mathrm{ha}^{-1}$ led to the greatest estimated banana yield.
2. The $\mathrm{B}$ rates increased the pulp/peel ratio, the pulp texture and the total B concentrations in the leaves and fruits.

3. Under the studied edaphoclimatic conditions, the $\mathrm{KCl} 1.0 \mathrm{~mol} \mathrm{~L}^{-1}$ extractant was equally effective to hot water in determining the available $\mathrm{B}$ in the soil.

\section{RESUMO}

Na Amazônia não existem informações sobre adubação com boro (B) na bananeira, além disso, o extrator água quente, que é atualmente o mais utilizado, apresenta inúmeras limitações. O objetivo deste trabalho foi estudar o efeito do B so- 
bre a produção e qualidade dos frutos da bananeira do subgrupo Cavendish (AAA), cultivada em Latossolo Amarelo distrófico, no Estado do Amazonas, Brasil. O delineamento experimental utilizado foi o inteiramente casualizado em parcela subdividida em esquema fatorial $4 \times 2$, constituído por quatro doses de B $\left(0,4,8\right.$ e $\left.12 \mathrm{~kg} \mathrm{ha}^{-1}\right)$ e dois ciclos de colheita - subparcelas (primeiro e segundo ciclo), com quatro repetições. A disponibilidade de $\mathrm{B}$ no solo foi determinada pelos extratores Mehlich 3, água quente e $\mathrm{KCl} 1,0 \mathrm{~mol} \mathrm{~L}-1$. A aplicação de $\mathrm{B}$ influenciou a produção, relação polpa e casca, resistência da polpa e o teor de $\mathrm{B}$ nas folhas e nos frutos. O extrator $\mathrm{KCl}$ 1,0 mol L ${ }^{-1}$ foi semelhante ao água quente na avaliação do $\mathrm{B}$ disponível. Para obtenção do máximo potencial de produção é necessário aplicar 4,1 e $6,1 \mathrm{~kg} \mathrm{ha}^{-1}$ de $\mathrm{B}$ no primeiro e no segundo ciclo, respectivamente.

Palavras-chave: Musa spp., produtividade, métodos de análise de solo, pós-colheita.

\section{REFERENCES}

Abreu MF, Abreu CA And Andrade JC. 2001. Determinação de boro em água quente usando aquecimento com microonda. In: RAIJ B, ANDRAdE JC, CANTARELla H AND QUAGGio JA (Eds), Análise química para avaliação da fertilidade de solos tropicais. Instituto Agronômico, Campinas, SP, Brasil, p. 231-239.

Alvarez Venegas VH, Novais RF, Barros NF, CataRUTTI RB AND LOPES AS. 1999. Interpretação dos resultados das análises de solos. In: RIBEIRO AC, GUIMARães PTG And Alvarez Venegas VH (Eds), Recomendação para o uso de corretivos e fertilizantes em Minas Gerais, $5^{\mathrm{a}}$ aproximação. SFSEMG, Viçosa, ES, Brasil, p. 25-32.

Bem-Arie R AND Sonego L. 1980. Pectolytic enzyme activity involved in woolly breakdown of stored peaches. Phytoch 18: 2553-2555.

Berger KC AND TRuog E. 1939. Boron determination in soils and plants using the quinalizarin reaction. Ind Eng Chem 11: 540-545.

Chapman VJ, Edwards DG, Blamey FPC And Asher CJ. 1997. Challenging the dogma of a narrow supply range between deficiency and toxicity of boron. In: BELL RW AND RERKASEM B (Eds), Boron in soil and plants. Kluwer Academic, Dordrecht, p. 151-155.

EMBRAPA- EMPRESA BRAsileira de PESquisA AgroPECUÁRIA. 1997. Manual de métodos de análise do solo. Embrapa Solos, Rio de Janeiro, RJ, Brasil, 212 p.
EMBRAPA - EMPRESA BRASILEIRA DE PESQUisa AgroPECUÁRIA. 1999. Sistema brasileiro de classificação de solos. Embrapa Solos, Rio de Janeiro, RJ, Brasil, 412 p.

FAGERIA NK. 2009. The use of nutrients in crops plants. CRC Press, Boca Raton, USA, 430 p.

FAO. 1990. FAO-Unesco Soil Map of the World. Soils Bulletin No. 60, Food and Agriculture Organization, Rome, Italy, $123 \mathrm{p}$.

FAOSTAT. 2008. Prodstat:crops. Food and Agriculture Organization, Rome, Italy. $<$ http://faostat.fao.org/default.aspx $>$. Accessed in 2010.09.09.

Ferreira GB, Fontes RLF, Fontes MPF AND Alvarez VENEGAS VH. 2001. Influência de algumas características do solo nos teores de boro disponível. Rev Bras Ci Solo 25: 91-101.

Gasparotto L, Pereira JCR, Pereira MCN And CosTA MM. 2002. FHIA 18: cultivar de bananeira resiste a sigatoka negra para o Estado do Amazonas. Embrapa Amazônia Ocidental, Manaus, AM, Brasil, 3 p.

GUPTA UC. 1993. Boron and its role in crop production. CRC Press, Boca Raton, USA, 237 p.

IBGE - Instituto BRAsileiro de Geografia E EsTATÍSTICA. 2008. <https://www.ibge.gov.br>. Accessed in 2010.09.09.

ISHII T, MATSUNAGA T AND HAYASHI N. 2001. Formation of rhamnogalacturonan II-borate dimmer in pectin determines cell wall thickness of pumpkin tissue. Plant Physio 116: 1698-1705.

Jin J, MaRTEns DC AND ZELAZNY LW. 1987. Distribution and plants availability of soil boron fractions. Soil Sci Soc Am J 51: 1228-1231.

LoOMIS WD AND DURst RW. 1992. Chemistry and biology of boron. Biofactors 3: 229-239.

LOUÉ A. 1993. Oligoéléments en agriculture. SCPA-NATHAN, Antibes, France, 577 p.

Malavolta E, Vitti GC and Oliveira AS. 1997. Avaliação do estado nutricional das plantas: princípios e aplicações. Potafos, Piracicaba, SP, Brasil, 319 p.

MARschner H. 1995. Mineral nutrition of higher plants. Academic Press, London, England, 888 p.

MeHLich A. 1984. Mehlich 3 soil test extractant; a modification of Mehlich 2 extractant. Comm Soil Sci Plant Anal 15: 1409-1416.

Moraes LAC, Moraes VHF And Moreira A. 2002. Relação entre a flexibilidade do caule de seringueira e a carência de boro. Pesq Agropec Bras 37: 1431-1436. 
Moreira A And CAStro C. 2006. Extratores ácidos e sais na determinação da disponibilidade de boro no solo. Embrapa Amazônia Ocidental, Manaus, AM, Brasil, 5 p.

Moreira A AND FAgEria NK. 2009a. Soil chemical attributes of Amazonas State, Brazil. Comm Soil Sci Plant Anal 40: 2912-2925.

Moreira A AND FAgERIA NK. 2009b. Repartição e remobilização de nutrientes na bananeira. Rev Bras Frut 31: 574-581.

Moreira A, Almeida MP, Costa DG And SAntos LS. 2004. Acidez potencial pelo método pH SMP no Estado do Amazonas. Pesq Agropec Bras 39: 89-92.

Moreira A, Pereira JC And Arruda Mr. 2005a. Avaliação do estado nutricional de bananais cultivados no Estado do Amazonas. Rev Ci Agra 40: 29-42.

Moreira A, Arruda Mr, Pereira JCR, Gasparotto L AND PEREIRA MCN. 2005b. Recomendação de adubação e calagem para bananeira no Estado do Amazonas, $1^{\mathrm{a}}$ aproximação. Embrapa Amazônia Ocidental, Manaus, AM, Brasil, 18 p.

Moreira A, Borges AL, Arruda MR And Pereira JCR. 2010a. Nutrição e adubação de bananais cultivados na região Amazônica. In: GASPAROTTO L AND PEREIRA JCR (Eds), A cultura da bananeira na região norte do Brasil. Embrapa Amazônia Ocidental, Manaus, AM, Brasil, p. 97-132.
Moreira A, Castro C And Oliveira FA. 2010b. Produção, teor de boro e avaliação de extratores em solos cultivados com soja. Ci Agrotec 34: 367-373.

Pimentel Gomes F And Garcia CH. 2002. Estatística aplicada a experimentos agronômicos e florestais; exposição com exemplos e orientações para uso de aplicativos. FEALQ, Piracicaba, SP, Brasil, 309 p.

SAlvador JO, Moreira A, Malavolta E ANd CABral CP. 2003. Influência do boro e do manganês no crescimento e na composição mineral de mudas de goiabeira. Ci Agrotec 27: 325-331.

Silva JTA, Borges AL And Malburg JL. 1999. Solos, adubação e nutrição da bananeira. Infor Agropec 20: 2136.

VIEIRA LS AND SANTOS PCTC. 1987. Amazon, its soils and other natural resources. Agronômica Ceres, São Paulo, SP, Brasil, 416 p. 